\title{
Planning conservation areas in Uganda's natural forests
}

\author{
Peter Howard, Tim Davenport and Fred Kigenyi
}

In the late 1980s the Ugandan Government decided to dedicate a fifth (3000 sq $\mathrm{km}$ ) of the country's 15,000-sq-km forest estate to management as Strict Nature Reserves (SNRs) for the protection of biodiversity. The Forest Department subsequently undertook a 5-year programme of biological inventory and socioeconomic evaluation to select appropriate areas for designation. Sixty-five of the country's principal forests (including five now designated as National Parks) were systematically evaluated for biodiversity, focusing on five 'indicator' taxa (woody plants, birds, small mammals, butterflies and large moths). A scoring system was developed to compare and rank sites according to their suitability for nature reserve establishment and 11 key sites were identified, which, when combined with the country's 10 national parks, account for more than 95 per cent of Uganda's species. In order to satisfy multiple-use management objectives, the Man and the Biosphere model of reserve design is being applied at each forest, by designating a centrally located core area as SNR, with increasingly intensive resource use permitted towards the periphery of each reserve and adjacent rural communities.

\section{Background}

Straddling the equator between Zaire and Kenya, Uganda is a comparatively small landlocked country of some $241,139 \mathrm{sq} \mathrm{km}$, of which one-fifth is inland water. Despite its modest size, the country encompasses a great variety of habitats, including deciduous Acacia-Commiphora bush, lowland evergreen rain forest, montane forest, snow-clad mountain peaks, open water and swamps. This diversity can be attributed to the country's location in a zone of overlap between ecosystems typical of East African savannah and Central African rain forest (Howard, 1991), and altitudes ranging from below $600 \mathrm{~m}$ at the bottom of the Rift Valley to over $5000 \mathrm{~m}$ at the top of the Rwenzori Mountains. Uganda ranks second in Africa (and ninth in the world) for its mammalian diversity, has more than half of the birds and a third of the butterflies listed for the continent (Howard, 1991; Pomeroy, 1993; Davenport and Matthews, 1995), and a higher proportion of Africa's plant phytochoria (plant 'kingdoms') than any other country in the continent (White, 1983). Much of this biodiversity is concentrated in the nation's forests, where it is at risk from encroachment, mismanagement and conflicting land-uses.

\section{Protected areas in Uganda}

Three principal categories of protected area are recognized in Uganda: National Parks, Game Reserves (recently renamed as Wildlife Reserves) and Forest Reserves. All support predominantly unmodified natural systems and are legally protected against any human settlement, cultivation or livestock grazing. Many have, nevertheless, suffered from uncontrolled hunting and/or selective removal of important timber trees, particularly over the past two decades (Kayanja and DouglasHamilton, 1989; Howard, 1991). Most of the game and forest reserves were designated during the first half of this century, when Uganda was under British Protectorate 
administration. The game reserves were established to protect large savannah mammals for hunting and cropping, while the forest reserves were set up to protect fragile mountain catchments, and to provide timber and other forest products. The original designation of many of these areas was made possible by land clearance associated with sleeping sickness epidemics in the early part of the century (Hamilton, 1984; Rogers and Randolph, 1988; Wasawo and Bushara, 1989). The first national parks (Murchison Falls and Queen Elizabeth) followed in the 1950s, through redesignation and consolidation of former game reserves, where particular concentrations of 'charismatic mega-fauna' and other attractions provided a basis for tourism development.

The Forest Department's jurisdiction covers about $15,000 \mathrm{sq} \mathrm{km}$ of land in about 700 forest reserves scattered across the country (of which about $3000 \mathrm{sq} \mathrm{km}$ now have dual status as Forest Reserve and National Park). More than two-thirds of Uganda's vegetation types (as described by Langdale-Brown et al., 1964) are represented in these reserves, including forest, woodland and open savannah communities. The reserves are managed to satisfy a variety of purposes including: the protection of fragile environments such as mountain catchments; provision of environmental services; protection of biodiversity; production of timber and other forest products; ecotourism; and meeting the subsistence needs of local human communities (Howard and Davenport, 1996). A few forest nature reserves were established in the larger forests during the 1950s, although it is now evident, with the development of conservation science and the benefit of hindsight, that these were not fully representative and were too small to remain viable in the longterm. Clearly, considerably larger areas were in need of preservation.

\section{Rationale}

Against this background, a decision was taken by the Ugandan Government towards the end of the 1980 s to manage 50 per cent of the forest estate primarily for environmental protection, with 20 per cent designated as Strict Nature Reserves (SNRs) and 30 per cent as lowimpact-use Buffer Zones. The remaining 50 per cent of the estate is to be managed primarily for the sustained supply of quality tropical hardwoods and other forest products. These broad allocations are to be achieved by applying the principles embodied in the Man and the Biosphere concept of reserve design, in which management zones are defined around a totally protected core (SNR), with zones of increasingly intensive use located towards the periphery of each reserve (Batisse, 1985; Howard, 1991). The 20-30-50 per cent allocations are broad national objectives, which can be achieved by designating particular reserves, or parts of reserves, to particular uses, according to each site's characteristics.

It is important that decisions concerning land allocation are implemented on the basis of a comprehensive knowledge of the resources under consideration within each reserve. However, prior to this programme very few data were available on the suitability of different areas for particular uses, and information on the biodiversity value of Uganda's forests was extremely limited. Species lists of selected plant and animal taxa have been compiled for a number of sites, but these have generally arisen incidentally as a result of other ecological investigations. Thus it was considered important to collect new field data on the biological values of the various reserves so that objective comparisons could be made and priorities established for the selection of the new nature reserves.

\section{Methods}

An unparalleled programme of biological inventory work was undertaken by the Forest Department between 1991 and 1995. With so many reserves in Uganda and the usual financial and technical constraints, it would have been impossible to investigate all sites, so a decision was taken to survey (1) those areas most likely to sustain viable populations of most species in the long term (namely the larger reserves exceeding $50 \mathrm{sq} \mathrm{km}$ ), and (2) 


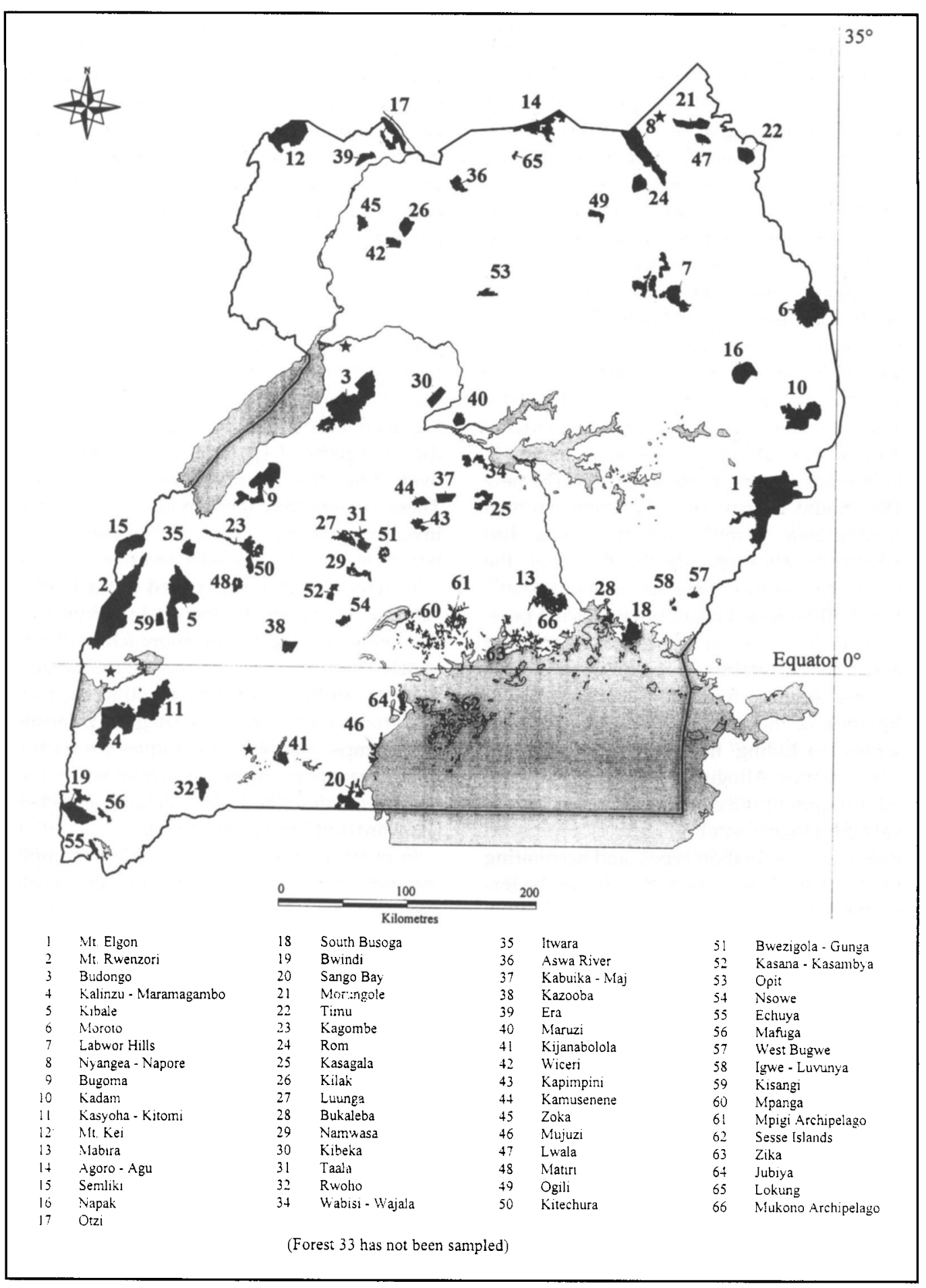

Figure 1. Map of Uganda showing the location of the 65 forests investigated during the inventory programme. 
any smaller reserve in which a particular vegetation type was uniquely represented. Reserves qualifying under the second of these criteria were identified at the project planning stage, when a 'gap analysis' (Scott et al., 1993) was carried out to assess the extent to which the country's vegetation types (LangdaleBrown et al., 1964) were already represented in the country's national parks, game reserves and larger forest reserves. An examination of the smaller reserves was then carried out to identify localities where 'missing' vegetation types occur, so that these sites could be included in the inventory programme.

Clearly, it would be inefficient to designate major sites from the forest estate as SNRs if the same suite of species is already managed within other existing protected areas. The new SNRs should be part of an efficient national protected-area system, which avoids unnecessary duplication. Ideally, therefore, the biological inventory programme would have covered all protected areas, but it was not possible to include any of the game reserves or older savannah national parks. Nevertheless, the programme provided a comprehensive evaluation of the country's principal forested reserves, including five now designated as national parks. Altogether, 65 forests distributed throughout the country were selected for detailed biological study (Figure 1), representing all major vegetation types, and accounting for more than 75 per cent of the area of the forest estate.

\section{Indicator taxa}

A number of taxa were selected for investigation, based largely on their suitability as biological 'indicators'. While debate continues over the value of indicators and their capacity to provide an accurate overall assessment of biodiversity, practical factors compel their use. Five taxa, as taxonomically different from one another as possible, were ultimately selected for study: woody plants; small mammals (five families: Cricetidae, Gerbillidae, Muridae, Myoxidae, Soricidae); birds; butterflies; and large moths (two families: Saturniidae, Sphingidae). By sampling these taxa the aim was to compile as complete a species list as possible for each site. Conservation priorities could then be established by comparing sites on the basis of species richness, diversity, rarity and complementarity, using directly comparable datasets. Furthermore, the study of specific taxa enabled the identification of localities for species of particular conservation concern.

\section{Field sampling}

Some ornithological and botanical work was initiated in 1991, but it was not until May 1992 that the programme was fully implemented. Eighteen Forest Rangers were selected from different parts of Uganda and provided with over 3 months of intensive field training. These rangers were then divided between four inventory teams, each comprising two botanists, one ornithologist and one mammalogist/entomologist, supervised in the field by full-time (graduate) biologists. In carrying out the fieldwork, the broad approach of the inventory teams was to explore the full range of habitats, altitude and aspect within each forest, from a number of strategically located base camps. Sampling techniques for each of the five taxa were based on current recognized methods, described in detail elsewhere (Howard and Davenport, 1996).

In practice, it is seldom possible to compile complete lists of species for any given site, even for the most conspicuous groups of plants and animals. It is therefore necessary to ensure that data collected from different sites are collected in a way that enables valid statistical comparison. Accordingly, field time was allocated in proportion to the size of each forest (thus standardizing as far as possible on sampling) and strict field recording procedures were maintained so as to track the rate of new species accumulation for each taxon with increased sampling effort. This facilitated later comparison between sites using species totals for given levels of sampling (Magurran, 1987; Krebs, 1989; Prendergast et al., 1993; Soberon and Llorente, 1993). Return visits were made to most forests during 1994 and the early part of 1995 and where possible, 
Table 1. Ranking of top 10 forests for species diversity and rarity value as exhibited by the five indicator taxa

\begin{tabular}{rll}
\hline Rank & Species diversity & Rarity value \\
\hline 1 & Kasyoha-Kitomit & Echuya \\
2 & Bwindi Impenetrable $^{*}+$ & Rwenzori* \\
3 & Budongot $^{*}$ & Moroto \\
4 & Kalinzu-Maramagambot & Bwindi-Impenetrable ${ }^{*} \dagger$ \\
5 & Kibale* & Mafuga \\
6 & Kadam & Mt Elgon* \\
7 & Mpanga & Budongot \\
8 & West Bugwe & Semliki* \\
9 & Mpigi & Kasyoha-Kitomit \\
10 & Kabuika-Mujwal'ganda & Kalinzu-Maramagambot \\
\hline
\end{tabular}

* Existing national parks

+ Forests appearing in both lists these took place at a different time of year and involved a different team of inventory rangers, so as to control as much as possible for these variables.

The fieldwork was completed in March 1995, and it took a further year to complete the identification and verification of specimens, and enter the data into a computer. The first stage of the analysis was then aimed at identifying 'biodiversity hotspots' - areas with an unusually large number of species or concentrations of rare species, which would be particularly suitable for designation as nature reserves. Each site was scored for biological importance based on a measure of species diversity (relative species richness), and the 'rarity value' of the species (based on frequency of occurrence in Uganda's forests, and known Africa-wide distributions; Forest Department, in prep.) represented within the five indicator taxa at each site. As shown in Table 1, the most biologically diverse sites are not necessarily those with the highest concentrations of rare species, and the biological importance score gave equal weighting to each of these two criteria. The next stage was to rank all 65 forests in terms of their biological importance.

\section{Balancing biological conservation and socio- economic development objectives}

This ranking process provided an unprecedented insight into the relative importance of Uganda's principal forests for biological conservation, but fell short of establishing clear site-selection priorities because it failed to take into account possible alternative demands on the same sites, for timber production, local community use, and so on. Clearly, conflicts of this nature should be avoided when possible.

The next stage of the site-selection process was, therefore, to evaluate each site for various alternative land uses - such as timber production, local community use, recreational use and watershed protection - and derive scores for each of these criteria. In doing this, scores were derived as objectively as possible using available data on standing timber volumes, population census statistics and so on, but more subjective assessments ('expert opinion') were necessary in deriving scores for certain criteria such as recreational potential (full details are provided in Forest Department, in prep.). These scores were then combined in a single statistic used as a measure of each forest's overall suitability for designation as Strict Nature Reserve. Thus, the highest scoring forests are those of high biological value located in important watershed areas with ecotourism development potential, where poor timber stocking combines with difficult access and low human population densities in surrounding areas to minimize the potential for land-use conflicts. 


\begin{tabular}{lcl}
\hline & & \\
\hline Site & $\begin{array}{l}\text { \% of species } \\
\text { added }\end{array}$ & $\begin{array}{l}\text { Cumulative \% of } \\
\text { species } \\
\text { represented }\end{array}$ \\
\hline Old (savannah) national parks* & $(36.9)$ & $(36.9) \ddagger$ \\
New (forest) national parkst & 40.1 & 77.0 \\
Budongo & 6.1 & 83.1 \\
Otzi & 3.3 & 86.4 \\
Moroto & 2.6 & 89.0 \\
Mt Kei & 1.1 & 90.1 \\
Sesse Islands & 1.1 & 91.2 \\
Labwor Hills & 0.9 & 92.1 \\
Sango Bay & 0.7 & 92.3 \\
Kasyoha-Kitomi & 0.7 & 93.6 \\
Nyangea-Napore & 0.6 & 94.2 \\
Kalinzu-Maramagambo & 0.5 & 94.7 \\
Timu & 0.5 & 95.1 \\
\hline
\end{tabular}

Table 2. Complementarity analysis based on representation of species from the five indicator taxa within existing national parks, and additional species to receive protection within the 11 key new forest nature reserves

* Queen Elizabeth, Murchison Falls, Kidepo Valley and Lake Mburo + Bwindi Impenetrable, Rwenzori Mountains, Mgahinga, Mt Elgon, Kibale and Semliki

$\ddagger$ Figures in parentheses are likely to underestimate the contribution of these parks because no comparable inventory work has been carried out and existing species' lists are probably far from complete

\section{Developing an efficient national protected-area system}

Scoring forests for nature reserve suitability in this way provides a reasonably objective means of ranking sites, but has the obvious disadvantage of failing to take into account the extent to which sites of similar rank support similar suites of species. An efficient protected-area system should, as far as possible, avoid unnecessary duplication, because any area dedicated exclusively to biodiversity conservation carries an opportunity cost in terms of alternative development opportunities foregone. Recognizing this, the next stage of the analysis was to investigate the optimum combination of sites required to protect the majority of species, using complementarity analysis (Margules et al., 1988; Johnson, 1995). This method selects the most species-rich site, followed by the one which complements it best, by adding the most 'new' species. Sites are added to the list in this way until all species are represented at least once. Such a list inevitably includes all the sites that support at least one unique species, and these make up the 'minimum critical set' of sites required to protect all species. Of course, in an ideal world, each species should be protected at a number of different sites, but the minimum critical set approach provides a useful starting point for protected-area system development.

\section{Planning management zones for particular sites}

The final stage of the programme involved detailed systematic vegetation sampling at each site to decide on which parts of a forest should be designated for different purposes. The procedure was based on quantitative enumeration of vegetation and human use in 0.1-ha plots distributed systematically on a $450 \times 450$ $\mathrm{m}$ grid covering the forest. From these plot data, computer-generated maps were derived to show the distribution of individual plant species, timber volumes and human-use variables. Ultimately these data fields were superimposed and analysed to generate optimal zoning regimes given clearly defined criteria. 


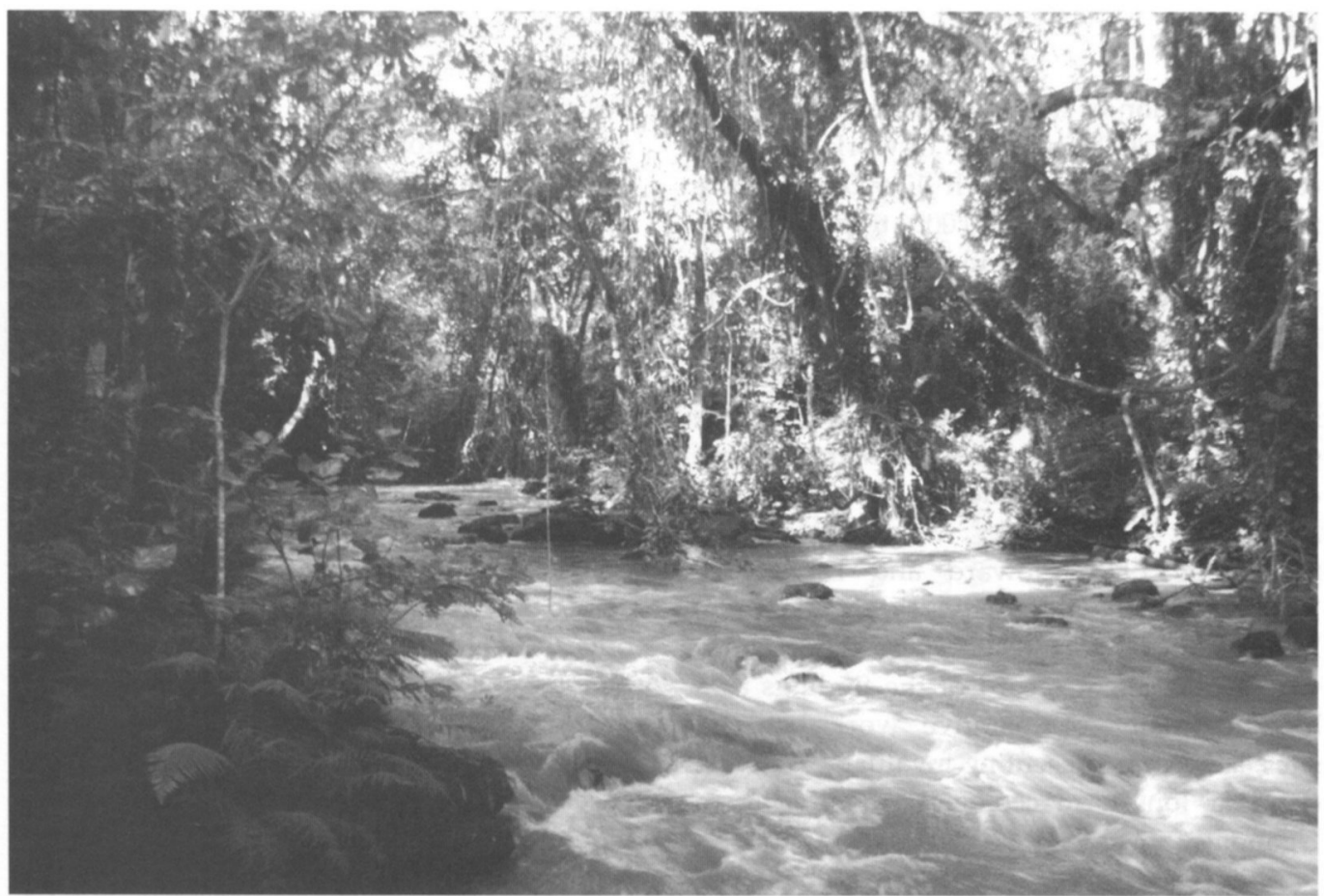

The Kyambura River flowing north-west through Kasyoha-Kitomi, the most species-rich forest investigated during the inventory programme (T. Davenport).

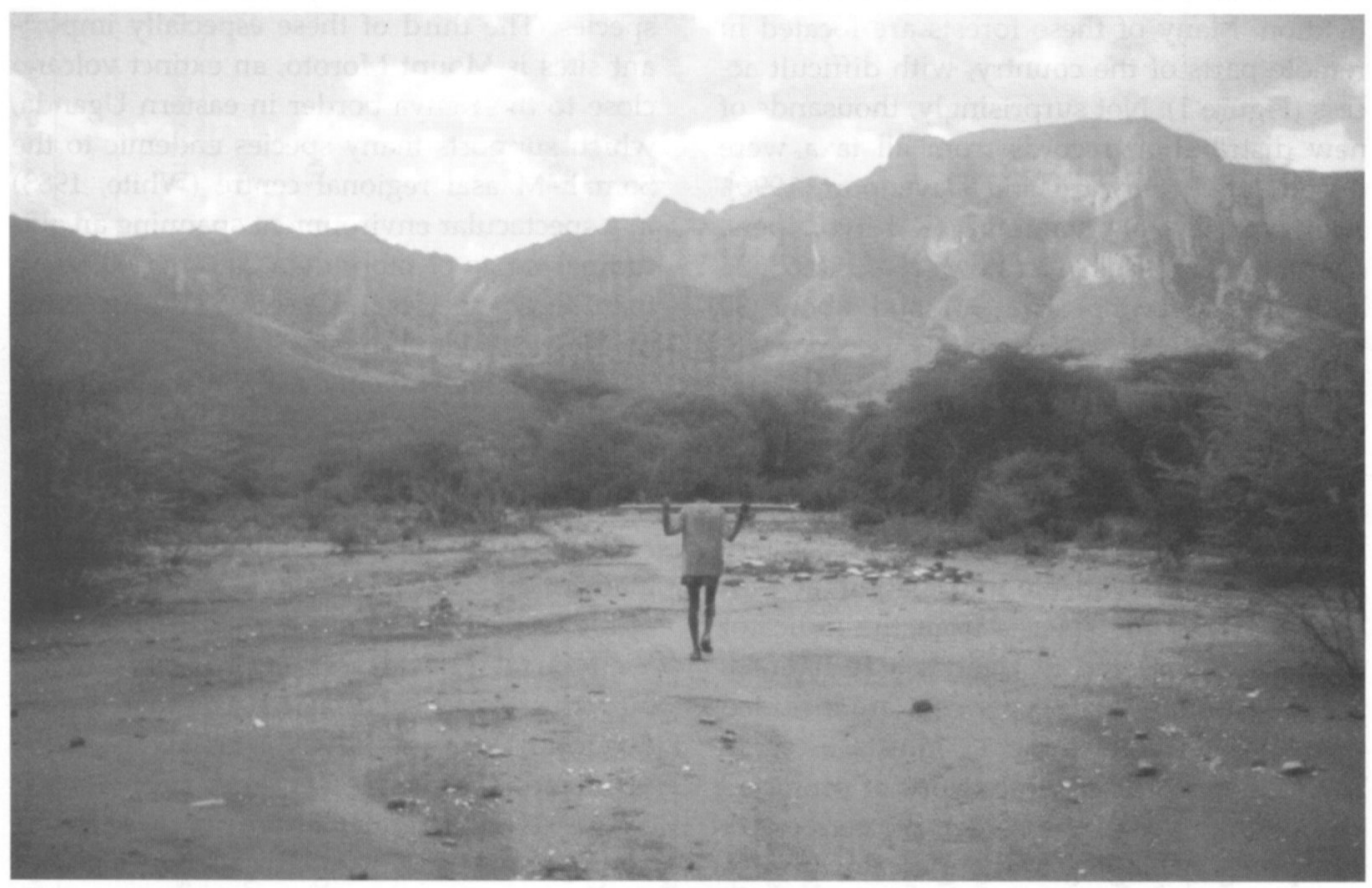

The steep-sided eastern slopes of Mt Moroto, viewed from the semi-arid savannah near the Kenyan border (T. Davenport). 


\section{Results}

On completion of the inventory work in early 1995, almost 100 man-years of work had been carried out, during which 17,600 plant site records were made, 100,000 trap-nights of small-mammal work undertaken and 57,000 large moths, 21,000 butterflies and 14,000 birds trapped (Howard and Davenport, 1996; Forest Department, in prep). The programme has become one of the most comprehensive scientific attempts to select sites for nature conservation in Africa. A 33-volume Biodiversity Report Series was completed in September 1996 (Howard and Davenport, 1996), describing the fieldwork and data collected from all 65 forests. These reports provide a permanent record of the findings as a basis for later comparative work between sites, as well as presenting invaluable baseline data for long-term ecological monitoring in Uganda's forests.

Although detailed ecological work had been carried out previously in a small number of the sites surveyed, the vast majority had not been the subject of any earlier biological investigation. Many of these forests are located in remote parts of the country, with difficult access (Figure 1). Not surprisingly, thousands of new distribution records from all taxa were documented (Howard and Davenport, 1996). Four species of mammal (R. Kityo, pers. comm.), three birds (Matthews et al., 1997), 36 butterflies (Davenport, 1996) and about 30 large moths new to Uganda were recorded, and a new species of silkmoth awaits description (A. W. R. McCrae, pers. comm.).

The national network of nature reserves identified as a result of this work comprises 11 key forests (Table 4), and c. 28 other secondary sites. Based on available information, at least 77 per cent of the species from the indicator taxa are represented in Uganda's 10 national parks and more than 95 per cent are included with the addition of the 11 forests listed in Tables 2 and 4 . The full network of protected areas would protect more than 98 per cent of the species belonging to the indicator taxa. A more detailed account of the national protected-area-system planning exercise and in- dividual site profiles are being provided in a Forest Conservation Masterplan (Forest Department, in prep).

The 11 key forests were selected primarily on the basis of their importance to the development of a representative national protectedarea system. Each is significantly different from any of the existing national parks (or other selected forests) in terms of species composition (Table 3) and physical geography (Table 4). Three forests are of outstanding importance because they contribute 12 per cent of the country's species (Table 2). Of these, Budongo is the only true forest, exceptionally rich in rain-forest fauna and flora, and situated between 700 and $1270 \mathrm{~m}$, elevations not otherwise represented in the new forested national parks. Otzi is a dry mountain range overlooking the Nile close to the Sudanese border in northern Uganda, where many species typical of White's (1983) Sudanian regional centre of endemism (which is not represented in Uganda's national parks) reach the southern limits of their ranges. Not long ago, white rhinoceros occurred here, and the reserve is still designated as a sanctuary for this species. The third of these especially important sites is Mount Moroto, an extinct volcano close to the Kenya border in eastern Uganda, which supports many species endemic to the Somali-Maasai regional centre (White, 1983) in a spectacular environment spanning an altitudinal range of more than $2000 \mathrm{~m}$. No fewer than three species of trees, 13 birds, three mammals, nine butterflies and eight large moths are known only from this site in the Ugandan parts of their ranges, and many of these are of international conservation interest (Table 3).

Of the other key forests, mention should be made of the Sesse Islands in Lake Victoria, one of the wettest places in the country. The Lake Victoria rat Pelomys isseli and the distinctive butterfly, Acraea simulata, for example, are endemic to these islands. Not far away on the mainland, the Sango Bay area supports the country's only significant area of swamp forest, a peculiar and distinctive association with its own special interest. 


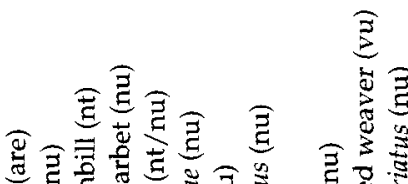

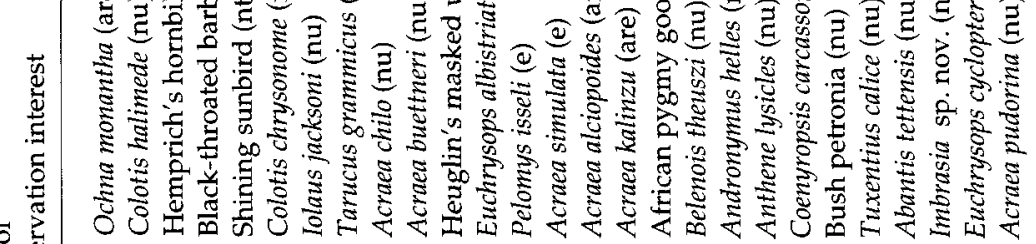

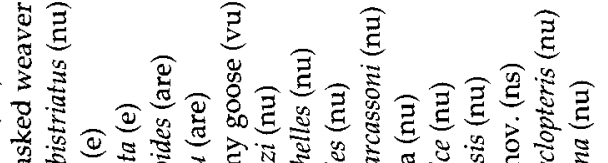

ก

承

畩.

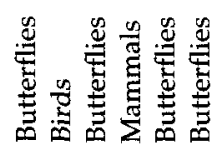

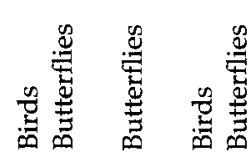

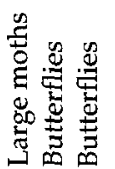

๐ำก

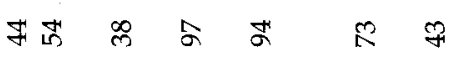

20

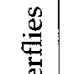

$\stackrel{\text { ๙ }}{\circ}$

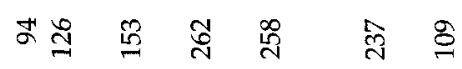

ิㅡㅅ

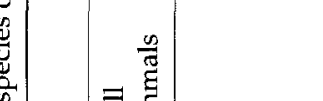

ก ก

สำ

$\infty \approx$

宽

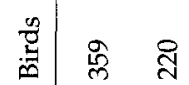

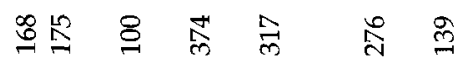

$\stackrel{\mathbb{1}}{\infty}$ 
Table 4. Descriptions of the 11 key forests for nature reserve establishment

\begin{tabular}{|c|c|c|c|}
\hline Forest & $\begin{array}{l}\text { Area } \\
(\mathrm{sq} \mathrm{km})\end{array}$ & $\begin{array}{l}\text { Altitude } \\
\text { (m) }\end{array}$ & Description \\
\hline Budongo & 793 & $700-1270$ & $\begin{array}{l}\text { Uganda's richest and most economically important mahogany } \\
\text { forest; the forested part occupies gently undulating land on top } \\
\text { of the escarpment along the Albertine Rift, with extensive } \\
\text { grassland and wooded areas on the scarp to the rift valley floor. } \\
\text { Contiguous with Murchison Falls National Park. }\end{array}$ \\
\hline Mt Moroto & 483 & $960-3084$ & $\begin{array}{l}\text { Steep extinct volcanic mountain in the dry Karamoja region of } \\
\text { eastern Uganda; wide range of vegetation types from dry semi- } \\
\text { desert to closed canopy montane forest above } 2000 \mathrm{~m} \text {. Occupied } \\
\text { by the Tepeth people, and seriously affected by tree cutting and } \\
\text { livestock damage. }\end{array}$ \\
\hline Otzi & 188 & $760-1667$ & $\begin{array}{l}\text { High ridge overlooking the Nile along the Sudan border in } \\
\text { northern Uganda. Dry Combretum savannah woodland with } \\
\text { rocky ridges, steep hillsides, plateaux, ravines, dense riverine } \\
\text { forest, bamboo and Protea communities. Formerly inhabited by } \\
\text { white rhinoceros. Low-lying riverine areas affected by } \\
\text { agricultural encroachment. }\end{array}$ \\
\hline Mt Kei & 384 & $915-1332$ & $\begin{array}{l}\text { Extensive area of flat Combretum-Terminalia-Butyrospermum } \\
\text { woodland with occasional granitic outcrops and narrow strips of } \\
\text { gallery forest along watercourses. Relatively pristine, but } \\
\text { subjected to frequent fire and intensive traditional group } \\
\text { hunting pressure. }\end{array}$ \\
\hline Sesse Islands & 43 & $1152-1262$ & $\begin{array}{l}\text { Extensive archipelago of islands in Lake Victoria, the wettest } \\
\text { region of Uganda. Dense moist evergreen rain forest on gently } \\
\text { undulating terrain interspersed with grassland, Papyrus swamp } \\
\text { and human settlements. Forest reserves generally small and } \\
\text { widely scattered making protection difficult. Increasingly } \\
\text { threatened by timber harvesting. }\end{array}$ \\
\hline $\begin{array}{l}\text { Kalinzu- } \\
\quad \text { Maramagambo }\end{array}$ & 584 & $915-1845$ & $\begin{array}{l}\text { Extensive area of tropical high forest, straddling the escarpment } \\
\text { along the eastern side of the Albertine Rift. Much of the drier } \\
\text { lower parts protected within Queen Elizabeth National Park, but } \\
\text { the important Kalinzu portion on top of the escarpment } \\
\text { threatened by operation of a recently rehabilitated sawmill. }\end{array}$ \\
\hline Sango Bay & 151 & 1160 & $\begin{array}{l}\text { Scattered blocks of dense Baikiaea-Podocarpus seasonal swamp } \\
\text { forest near the Lake Victoria shore; of generally low stature, } \\
\text { supporting a peculiar community of species with many } \\
\text { Afromontane affinities. }\end{array}$ \\
\hline $\begin{array}{l}\text { Kasyoha- } \\
\text { Kitomi }\end{array}$ & 399 & $975-2136$ & $\begin{array}{l}\text { Large block of tropical high forest on steeply undulating terrain, } \\
\text { overlooking the Albertine Rift. Inaccessible and little known } \\
\text { prior to this project. Exceptionally diverse. }\end{array}$ \\
\hline Labwor Hills & 437 & $1050-1925$ & $\begin{array}{l}\text { Isolated group of steep hills rising above the dry plains of north- } \\
\text { eastern Uganda; woodland and grassland communities with } \\
\text { patches of dry montane and riverine forest on hilltops and along } \\
\text { gulleys. }\end{array}$ \\
\hline $\begin{array}{l}\text { Nyangea- } \\
\text { Napore }\end{array}$ & 417 & $1060-2284$ & $\begin{array}{l}\text { Spectacular granitic ridge along the western flank of Kidepo } \\
\text { Valley National Park, bordering Sudan in the dry north-eastern } \\
\text { corner of Uganda. Remote and little-known, supporting } \\
\text { woodland communities and isolated remnant patches of dry } \\
\text { montane forest. }\end{array}$ \\
\hline Timu & 117 & $1700-2020$ & $\begin{array}{l}\text { A shallow wooded basin on the top of the escarpment above } \\
\text { Uganda's eastern border with Kenya, with patches of Juniperus } \\
\text { dry montane forest. Remote and inaccessible, but affected } \\
\text { recently by agricultural encroachment. }\end{array}$ \\
\hline
\end{tabular}


Although the site-selection work has been completed, only three sites have been the subject of detailed systematic vegetation plot sampling aimed at providing the data necessary for sound planning of management zones within individual sites. Itwara and Semliki forests in western Uganda were sampled initially to evaluate, and if necessary modify, the technique for subsequent adoption elsewhere. Further work was carried out at Kalinzu and Kasyoha-Kitomi, but it soon became apparent that the cost of such intensive sampling was prohibitive, and difficult to justify.

Instead, management zones are now being planned within the selected key forests, on the basis of observations made during the broader species-inventory work. Where possible, a substantial undisturbed core area of each forest, covering the widest possible range of altitude and variety of vegetation types, is being selected for designation as SNR. An important consideration is the location of natural features, such as streams and ridges that can serve as clear internal boundaries between management zones. Special consideration is being given to the needs of local people and areas within $2 \mathrm{~km}$ of a forest boundary are generally designated for community use and / or sustainable timber harvesting, rather than exclusive nature conservation.

\section{Conclusions}

The nature reserve planning exercise represents a major commitment on the part of the Ugandan Government, the international donor community and Forest Department staff. It has taken more than 5 years to complete, at a cost of around \$US1 million. The challenge now is to transform the resulting plans into management programmes that are viable in the long term, beyond the tenure of foreign aid.

Several factors give cause for optimism in this respect. First, because the planning work was carried out by government, and relates directly to current policy, it clearly has the necessary political support. Second, it has been carried out as part of an ongoing, inte- grated forest-management programme, which can be readily adapted to accommodate the emerging priorities. The broader forestry rehabilitation programme (Tabor et al., 1990; Howard, 1991) has (among other things) improved the protection and management of many of Uganda's natural forests by re-establishing forest boundaries, providing basic management infrastructure, staff training and logistical support. This work has helped secure important sites in the short term, so that those now identified for nature reserve establishment can be developed appropriately.

Continued support is required, however, if the programme is to be implemented fully and successfully. This must come from government, local communities and the international donor community. International finance, provided through arrangements such as the Global Environmental Facility, is essential as a means of offsetting some of the opportunity costs incurred locally when nature reserves are designated in areas that could otherwise have been used profitably in some other way.

\section{Acknowledgements}

The programme was supported by the EC-funded Natural Forest Management and Conservation Project (No. 6100.37.42.015) and the Global Environment Facility's Institutional Support for the Protection of East African Biodiversity (UNO/RAF/006/GEF), financed through UNDP/FAO. A great many people contributed to this work and particular thanks are extended to colleagues Michael Baltzer, Chris Dickinson, David Duli, David Hafashimana, Isaac Kapalaga, Tony Katende, Robert Kityo, Jerry Lwanga, Roger Matthews, Edward Mupada, Robert Nabanyumya and Paolo Viskanic, all of whom contributed greatly to the management of the programme. We are most grateful to Tom Butynski and Vernon Reynolds for helpful comments on an earlier version of this paper.

\section{References}

Batisse, M. 1985. Action plan for biosphere reserves. Environmental Conservation, 12 (1), 17-27.

Davenport, T.R.B. and Matthews, R.A. 1995. A wealth of species come to light - Uganda's forest biodiversity. Swara, 18 (3), 26-29.

Davenport, T.R.B. 1996. The Butterflies of Uganda. An Annotated Checklist. Uganda Forest Department, 
Kampala, Uganda.

Forest Department, in prep. Nature Conservation Masterplan. Uganda Forest Department, Kampala, Uganda.

Hamilton, A.C. 1984. Deforestation in Uganda. Oxford University Press, Nairobi, Kenya.

Howard, P.C. 1991. Nature Conservation in Uganda's Tropical Forest Reserves. IUCN, Gland, Switzerland and Cambridge, UK.

Howard, P.C. and Davenport, T.R.B. (eds). 1996. Forest Biodiversity Reports. Vols. 1-33. Uganda Forest Department, Kampala, Uganda.

Johnson, N. 1995. Biodiversity in the Balance: Approaches to Setting Geographic Conservation priorities. Biodiversity Support Programme, Washington DC.

Kayanja, F.I.B. and Douglas-Hamilton, I. 1989. The impact of the unexpected on the Uganda National Parks. In National Parks, Conservation and Development (eds J. A. McNeely and K. R. Miller), pp. 87-93. Smithsonian Press, Washington DC.

Kingdon, J. 1971-74. East African Mammals: An Atlas of Evolution. Academic Press, London.

Krebs, C.J. 1989. Species Diversity Measures. Ecological Methodology. Harper and Row, New York.

Langdale-Brown, I., Osmaston, H.A., and Wilson, J.G. 1964. The Vegetation of Uganda and its Bearing on Land-use. Government Printer, Entebbe.

Magurran, A.E. 1987. Ecological Diversity and its Measurement. Chapman and Hall, London.

Margules, C.R., Nicholls, A.O. and Pressey, R.L. 1988. Selecting networks of reserves to maximise biological diversity. Biological Conservation, 43, 63-76.

Matthews, R.A., Baltzer, M.C. and Howard, P.C. 1997. New bird records for Uganda, with an addition to the East African avifauna. Scopus, 19, 119-120.
Pomeroy, D. 1993. Centres of high biodiversity in Africa. Conservation Biology, 7 (4), 901-907.

Prendergast, J.R., Wood, S.N., Lawton, J.H. and Eversham, B.C. 1993. Correcting for variation in recording effort in analyses of diversity hotspots. Biodiversity Letters, 1, 39-53.

Rogers, D.J. and Randolph, S.E. 1988. Tsetse flies in Africa: bane or boon? Conservation Biology, 2 (1), $57-65$.

Scott, J.M.. Davis, M., Csuti, B., Noss, R., Butterfield, B., Groves, C., Anderson, H., Caicco, S., D'Erchia, F., Edwards, T.C., Ulliman, J. and Wright, R.G. 1993. Gap analysis: a geographic approach to protection of biological diversity. Wildlife Monographs, $123,1-41$.

Soberon, J.M. and Llorente, J.B. 1993. The use of species accumulation functions for the prediction of species richness. Conservation Biology, 7 (3), 480-488.

Tabor, G., Johns, A. and Kasenene, J.M. 1990. Deciding the future of Uganda's tropical forests. Oryx, 24 (4), 208-214.

Wasawo, D.P.S. and Bushara, J. 1989. Wildlife and Protected Areas. Strategic Resources Planning in Uganda. Vol. III. United Nations Environment Programme, Nairobi.

White, F. 1983. The Vegetation of Africa. UNESCO, Paris.

Peter C. Howard, Ghana Wildlife Department, PO Box M239, Ministry Post Office, Accra, Ghana.

Timothy R. B. Davenport, WWF-Cameroon, PO Box 6776, Yaounde, Cameroon.

Frederick W. Kigenyi, Forest Department, PO Box 1752, Kampala, Uganda. 